\title{
Para Ana Lugão (1960-2012)
}

\author{
Monica Grin \\ Universidade Federal do Rio de Janeiro \\ Rio de Janeiro, RJ, Brasil \\ monica.grin@gmail.com \\ Hebe Mattos \\ Universidade Federal Fluminense \\ Niterói, RJ, Brasil \\ hebe.mattos@gmail.com
}

Era o ano de 2001 ou 2002, não me recordo bem. Anunciava-se no Programa de Pós-graduação em História (PPGHIS) uma palestra da professora Ana Maria Lugão Rios sobre Victor Nunes Leal (o título dizia mais do que isso). Decidi conhecer de perto a colega, aparentemente formal, recém-chegada ao Departamento de História. Fiquei curiosa: o que essa nova professora teria a dizer sobre esse autor cuja obra conhecia bem dos tempos do Instituto Universitário de Pesquisa do Rio de Janeiro (Iuperj)? Fui conferir.

Impressionei-me de imediato. Assertiva em seus argumentos, Ana desafiava as teses de Victor $\mathrm{Nu}-$ nes Leal, sob o olhar orgulhoso de seu orientador lá presente, Stuart Schwartz. Desafiava Coronelismo, enxada e voto com fontes formais, memória coletiva sobre escravidão, histórias de tradiçóes familiares rurais, repletas de imagens, relatos de alegria e sofrimento, colhidas através do método da história oral. Ana, naquela tarde, sugeria curiosas articulaçóes entre o contexto do pós-aboliçáo e a memória da escravidáo. As pequenas histórias relatadas mostravam um Brasil rural e camponês mais diverso, mais qualificado, mais individualizado. Nada próximo das massas camponesas subalternizadas e submetidas ao mando de coronéis. Grande parte dessa pesquisa sairia anos mais tarde em seu livro com Hebe Mattos, Memórias do cativeiro. O esforço de Ana Lugão era dar "cara" e agência aos libertos e a seus descendentes espalhados por esse Brasil. Mostrou-se corajosa, assertiva e provocativa em sua crítica a Victor Nunes Leal, embora àquela altura ainda tivesse dúvidas sobre a pertinência dessas críticas. Seu jeito, ainda assim, me encantou.

Daquele momento nasce minha admiraçáo intelectual por Ana e meu respeito e interesse pela pesquisa histórica que ela desenvolvia. Aos poucos fui me aproximando, conhecendo-a mais de perto. Da colega de aparência formal, algo rígida, foi se revelando uma amiga sedutora, com ironia finíssima, particularmente espirituosa, dotada de inteligência e sagacidade. Ana possuía inabalável princípio de justiça ao qual me apegava como se fosse uma bússola a orientar minhas decisóes e juízos sobre o mundo.

Ao mesmo tempo simples, curiosa da "vida como ela é", torcedora fanática do Flamengo (o toque do seu celular era o hino do Flamengo), amante da boa literatura (tinha uma cultura literária sólida), solidária e cúmplice.

Ana adoece poucos anos depois e, entre curas e recidivas de um maldito câncer, nossas afinidades se estreitaram e nossos interesses intelectuais se afinaram. Nesse tempo, antes de sua aposentadoria, oferecíamos cursos sobre pós-abolição com alguma regularidade e nesse processo me dei conta, sob sua influência, de que o campo dos estudos do pós-abolição merecia toda a nossa atenção e que era inadiável sua consolidação no PPGHIS. E ela tinha toda razão. Sob sua orientação, muitas vezes interrompida pelos altos e baixos da doença, boas teses e dissertaçóes foram e estão sendo defendidas. Seus trabalhos no 
Laboratório de História Oral e Imagem da Universidade Federal Fluminense (Labhoi-UFF), com Hebe Mattos e Marta Abreu, estáo dando frutos incríveis: livros, filmes, teses, seminários internacionais etc. Não tenho dúvida de que sua reflexão, metodologia e pesquisa pavimentam no Brasil os estudos sobre pós-abolição. O legado e o pioneirismo de Ana nessa área são reconhecidos e merecem ser cultivados.

Nos últimos dois anos tive poucas oportunidades de estar com Ana, embora nossos telefonemas fossem frequentes. Impressionava, ao telefone, o vigor de sua voz e a vivacidade das suas ideias, que noite adentro desfrutava, ela lá e eu cá.

Sabia e já tinha visto algumas vezes, e não sem espanto, seu debilitado estado físico e aquela dor, aquela maldita dor. Mas, nem por um segundo, a voz forte, a risada contagiante, a lucidez inabalável deixavam revelar suas reais condiçôes físicas. Quando perguntava: "Ana, como você está?” Ela apenas dizia: "Querida, vamos falar da sua vida? O que você está lendo? O que você tem feito? Como está o IFCS?”. Falávamos sobre tudo, menos sobre a sua dor. Quando a dor apertava, ela simplesmente dizia: "Estou com sono, vamos desligar?".

A última conversa que tivemos, acho que uma semana antes de sua morte, ela apressadamente me informava sobre um texto que concluiu, na verdade um conto, uma história de ficção, como ela dizia, de nome "Pimenta indigesta", e que Marta Abreu e Cuca Machado sabiam do que se tratava. Fiquei comovida com a notícia de sua inesperada produção. Ela generosamente insistia para que eu participasse da coletânea (Cativos, forros e negros da terra: entre a história e a imaginaçâo) na qual sairia seu conto. Disse a ela que precisava de um tempo, pois acabara de chegar de viagem e estava com a agenda lotada de compromissos. Ingenuidade minha... O que ela não tinha era tempo.

O texto de ficção a que se refere Monica Grin está mesmo com Martha Abreu, um delicioso conto construído a partir da tradição oral dos moradores do Quilombo do Bracuí. Foi concebido para um livro coletivo que Ana buscava organizar com Cacilda Machado. A coletânea propunha completar com imaginação os não ditos dos arquivos, estimulando historiadores sociais a explorar o terreno da ficção. Concluir o projeto do livro, como concebido pelas organizadoras, foi o último desejo de Ana em termos profissionais, vale a pena tentarmos concretizá-lo. Em homenagem a ela, entretanto, o conto vai ser publicado antes, no livro resultante do Seminário Internacional Histórias do Pós-Abolição no Mundo Atlântico, acontecido na UFF entre 14 e 16 de maio de 2012. Uma iniciativa que Ana ajudou a conceber, mas da qual não pôde participar.

No seminário, uma das áreas de fronteira exploradas foi a da história pública. Refletimos sobre o papel do historiador na construção da imaginação histórica a respeito da escravidão e do pós-abolição. Em especial, as relaçôes possíveis entre história e ficção foram objeto da conferência de Myriam Cottias, que analisou seu próprio papel como corroteirista da minissérie Tropiques amers, escrita para um canal da televisão francesa, sobre o contexto da escravidão e do pós-abolição na Martinica. Eis que descobrimos que Ana, sempre pioneira, havia feito exercício semelhante e com belíssimo resultado!

As duas referências vistas — coletânea e seminário — possibilitam uma aproximação interessante com o perfil acadêmico de Ana Lugão Rios. Deixam em destaque, por um lado, o sentido de inovação de suas iniciativas para o pós-abolição como campo de estudo. Por outro, evidenciam seu gosto pelo trabalho coletivo, sempre desenvolvido como troca e sem abrir mão de sua marca pessoal - características marcantes de seu legado intelectual.

Estreitei minha amizade com Ana nos idos de 1988, quando fazíamos, ela, o mestrado na UFF, e eu, o doutorado, com a mesma orientadora, Maria Yedda Linhares. Na dissertaçáo de mestrado que então desenvolveu (1990), Ana começaria a desbravar e a conceituar o pós-abolição como campo de 
estudos, em diálogo com os esforços que eu fazia no mesmo sentido em minha pesquisa de doutorado. As principais contribuiçóes de seu mestrado foram retomadas em dois artigos que publicamos em conjunto muitos anos depois, um nesta mesma revista Topoi, número 8, em 2004, com o título "Sobre o pós-abolição como problema histórico", e outro no livro Quase cidadão (2007), organizado por Flávio Gomes e Olívia Cunha, com o título "Para além das senzalas". Destaco, especialmente, suas contribuiçôes para analisar a importância da agência do liberto como variável social e política após o 13 de maio e o papel da família como espaço de disputa política naquele contexto.

Em 1994, desenvolvemos um primeiro projeto conjunto sobre o pós-abolição, com a intenção de aprofundar nossa experiência com o método da história oral. Durante o doutorado na Universidade de Minneapolis, Ana desenvolvera seu modelo de entrevista genealógica, combinando elementos clássicos dos usos antropológicos da genealogia com a experiência africanista de recolha de tradição oral como fonte para a história. Bingo! Aos poucos a metodologia proposta por ela se tornaria a principal ferramenta a alimentar o arquivo oral "Memórias do cativeiro" do Labhoi.

Memórias do cativeiro. Família, trabalho e cidadania no pós-abolição (2005) foi o livro que consolidou os resultados de nossas trajetórias de pesquisa no tema, dialógicas e complementares. Texto polifônico, em que a minha voz e a de Ana se somavam à de nossos muitos interlocutores. O livro consolidaria a importância da família e da mobilidade como elementos constituintes da ética de trabalho que marcara a inserçâo social dos libertos do Sudeste após a abolição. Verdadeiro "campesinato itinerante", segundo a feliz síntese de opostos proposta por Ana.

O livro nos levou ao filme (Memórias do cativeiro, 2005), já em parceria com Martha Abreu, e a consultoria de Ana se manteve fundamental em todo o trabalho de registro audiovisual desenvolvido por nós a partir de então. Ana então começava a lutar contra o câncer, com uma energia absolutamente admirável. O conto "Pimenta indigesta", a ficção a que me referi no início do texto, é fruto do trabalho conjunto que desenvolvemos no período, origem do documentário Jongos, calangos e folias. Música negra, memória e poesia (2007). A imagem e a voz de Ana discutindo o destino dos libertos após a abolição estão ali imortalizadas.

Em "Pimenta indigesta", Ana faz um trabalho de arquivo e de imaginação, com base na tradição oral dos camponeses negros de antiga fazenda de desembarque ilegal de escravos em Angra dos Reis. Aliás, a presença africana, o tráfico ilegal e a escravidão no sul fluminense foram alvos frequentes dos sempre instigantes textos de Ana. "Não se esquece um elefante: notas sobre os últimos africanos e a memória d'África no vale do Paraíba”, publicado em livro editado por João Fragoso, Manolo Florentino, Antônio Carlos Juca e Adriana Campos, é um deles, imperdível (2006). Na melhor tradição de suas parcerias cheias de personalidade, seu texto de 1995, com João Luis Fragoso, para o livro Resgate. Uma janela para o Oitocentos, já tinha a marca inconfundível de sua reflexão singular sobre agência e subjetividade na história.

Para terminar, entretanto, é preciso voltar ao tema com que Monica Grin começou este texto, a crítica às teorias do coronelismo, parte da tese de doutorado de Ana que não incorporamos ao Memórias do cativeiro e que, apenas parcialmente, está presente em "Para além das senzalas". Ana publicou sua reflexão sobre o tema somente em 2007, no Cadernos IHU Ideias, da Unisinos, com o título "Campesinato negro no período pós-abolição: repensando Coronelismo, enxada e voto". Reflexão quase clandestina, mas simplesmente seminal. Os argumentos ali apresentados por Ana são instigantes e inspiradores, ainda que iniciais. Estabeleceram uma pauta de pesquisa inovadora, que insere a agência dos libertos como variável central para pensar a política e as práticas coronelistas na Primeira República. Tal agenda de pesquisa começa a dar frutos, em pesquisas docentes, dissertaçóes e teses em andamento, como ficou claro no seminário organizado na UFF. A simples ousadia de formular a questão já possibilita interessantes releituras sobre os processos políticos da Primeira República, e foi um de meus faróis ao aceitar 
o desafio de escrever um texto de síntese sobre a história política do período para o terceiro volume da série História do Brasil nação, organizada por Lilia Schwarcz. O tempo para Ana foi curto, mas suficiente para que nos deixasse um legado intelectual inestimável.

É com emoção que termino de escrever este pequeno texto em parceria com Monica Grin em homenagem a Ana Lugáo, polifônico como a minha escrita e a de Ana em Memórias do cativeiro. Ana era generosa e me apoiou inúmeras vezes em que precisei de sua amizade. Conheci sua filha, Eduarda, ainda bebê, em Minneapolis, onde vivia com seu então companheiro e amigo de toda vida, João Fragoso. Desbravamos juntas a Highway One, na Califórnia, em uma viagem inesquecível. Nos últimos anos, eu, covarde, náo conseguia acompanhar sua dor, mas todas as vezes em que ela melhorava um pouco me ligava, e fazíamos uma festa de pijama, em que revivíamos nosso mantra de amizade e de cumplicidade intelectual.

Salve, Ana! 